\title{
"The role of political will in enhancing e-government: An empirical case in Indonesia"
}

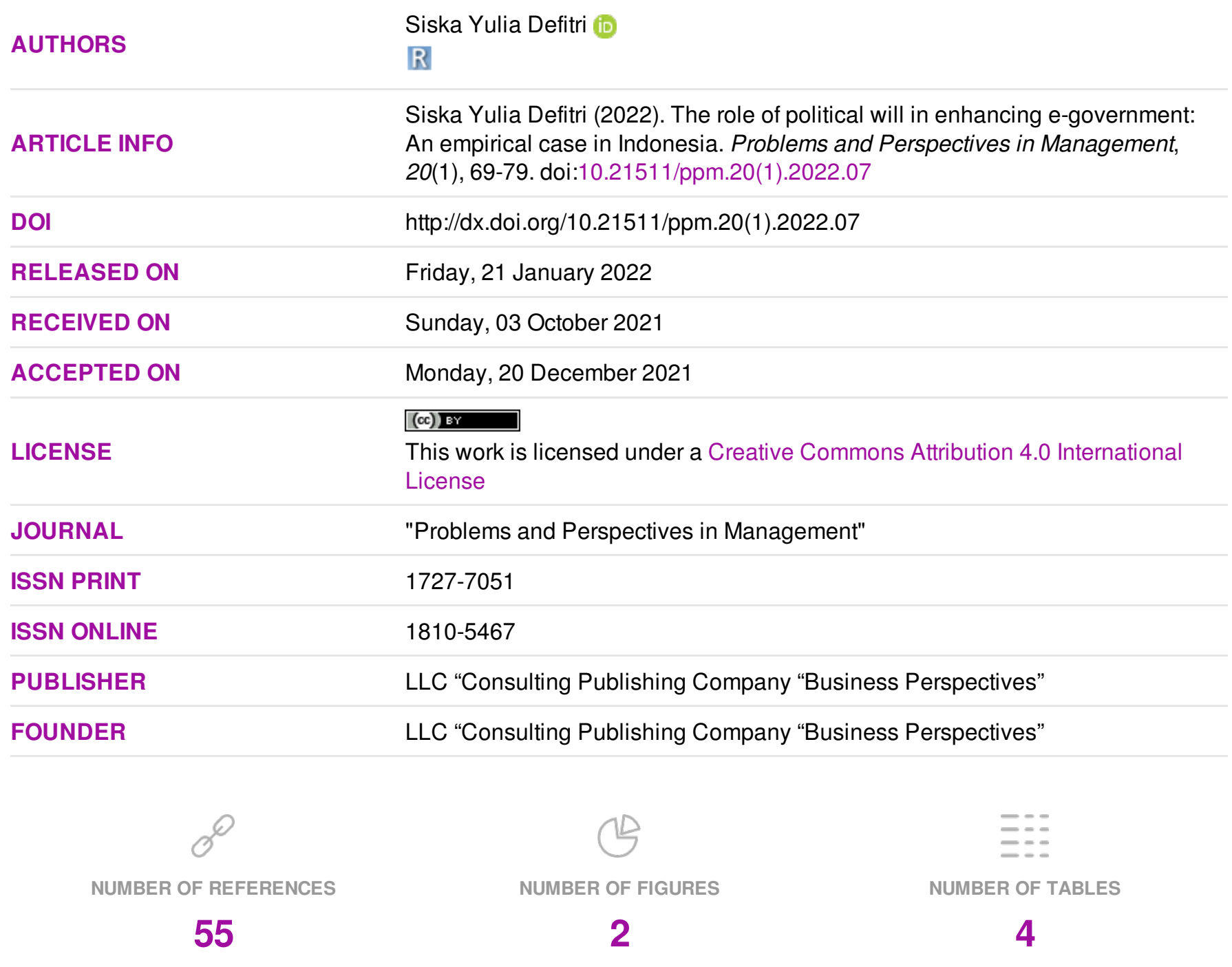

(c) The author(s) 2022. This publication is an open access article. 


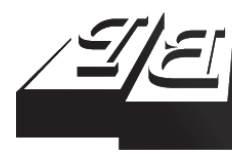

BUSINESS PERSPECTIVES

LLC "CPC "Business Perspectives" Hryhorii Skovoroda lane, 10, Sumy, 40022, Ukraine www.businessperspectives.org
Received on: $3^{\text {rd }}$ of October, 2021 Accepted on: $20^{\text {th }}$ of December, 2021 Published on: $21^{\text {st }}$ of January, 2022

(C) Siska Yulia Defitri, 2022

Siska Yulia Defitri, Ph.D., Lecturer, Faculty of Economics, Department of Accounting, Universitas Mahaputra Muhammad Yamin, Indonesia.

\section{THE ROLE OF POLITICAL WILL IN ENHANCING E-GOVERNMENT: AN EMPIRICAL CASE IN INDONESIA}

\begin{abstract}
E-government is an issue that is widely discussed by several studies because it has an impact on improving government performance. Weak political will of the heads of state and regional heads reduces attention to e-government, combined with various obstacles to its implementation. This study can answer the importance of the role of political will in maximizing the implementation of electronic government in local government. A total of 263 data were collected to answer the hypothesis quantitatively. The data were obtained by distributing questionnaires directly to the respondents, namely the Heads of Regional Apparatus Organizations (OPD). The sample selection was carried out with regional heads. Data were tested through multivariate analysis using Partial Least Square-Structural Equation Modeling (PLS-SEM). The test results found that political will has a direct positive effect on the implementation of e-government as evidenced by the path coefficient of 0.457 and significant wit $h$ an alpha of $5 \%$. Political will also acts as a mediating variable or can act as an intermediary in the relationship between IT infrastructure and human resources in improving e-government. All variables have a T-statistic value $>1.96$ and $<5 \%$, which means that IT infrastructure and human resources have a direct and significant effect on the implementation of e-government.
\end{abstract}

\section{Keywords electronic government, political will, infrastructure, local government, information technology, human resource}

\section{JEL Classification H76, O38, P26}

\section{INTRODUCTION}

In the last decade, digital governance has become an interesting issue to be discussed in various countries around the world. This is inseparable from technology developments that are increasing rapidly and helping to improve organizational performance (Pfano \& Beharry, 2016). One of the indicators of digital government is the implementation of electronic government (e-government). E-government is the use of technology in government activities that can improve services to the community. In general, the implementation of e-government is already in a position of maturity in developed countries but is different from developing countries (Weerakkody et al., 2009). This is due to various factors that affect the success of e-government, namely the availability of information technology infrastructure (ICT) and competence of human resources (Muhaya et al., 2015).

Perceived ICT infrastructure is one of the top success factors for egovernment in developing countries (Apleni \& Smuts, 2020). It is proven by the test results that ICT infrastructure has a positive relationship with e-government implementation (Dahwan \& Raju, 2021). The same applies to human resources that have a significant influence on e-government implementation (Kumajas, 2021). Human resources are part 
of the organizational aspects that play a role in achieving organizational performance through the use of technology. Weak infrastructure and low competence of human resources can slow down technology adoption (Michael et al., 2018; Ramli, 2017) that will create obstacles in developing countries (Dada, 2006; Odat, 2012; Weerakkody et al., 2011), which should be overcome by the government.

Politics is also a combined factor in influencing e-government (Apleni \& Smuts, 2020). However, the political contribution in e-government performance reports is still low (Stier, 2015). One of the political issues that can play a dominant role in decision-making is political will. Political will is a commitment shown by people in decision-making positions such as heads of state or regional heads, to be able to act in overcoming the problems and policies they face (Hammergren, 1998).

Political will has started to become a topic of discussion in corruption studies (Kpundeh, 1998). However, the issue of political will is now starting to be included in other fields such as poverty policy (Rasyid \& Dulkiah, 2020), education (Aboluwodi, 2015), and irrigation (Ishaq, 2018). Developing countries tend to have the low political will to utilize technology (Nkohkwo \& Islam, 2013). This issue has not been discussed empirically in its application in e-government, especially in Indonesia, so that it becomes a contribution to this research. However, the head of government can prioritize and focus on government implementation by investing in e-government (Manenji \& Marufu, 2016), since many advantages can be utilized by implementing e-government, including economic improvement (Adam, 2020), effectiveness and efficiency of public services (Ariana et al., 2020), overcoming corruption (Adam, 2020), public accountability (Defitri et al., 2020) and quality of life (Danyliuk et al., 2021).

\section{LITERATURE REVIEW}

The conceptual model of technology adoption uses the logical adoption behind the implementation of information systems and the sustainability of their use. Currently, the adoption of technological innovations is universally considered an important tool in improving services within the scope of government. It is generally accepted today that technological innovation has a significant effect on government productivity. This effect will only be fully realized if, and when, technological innovations are widespread and used. Therefore, it is important to understand the determinants of technological innovation adoption and the theoretical models that have emerged in response to technological innovation adoption. The effectiveness of innovation can become even more important to decision-makers. Dearing and Cox (2018) state that policy enforcement can be a more predictor of policy adoption. With policy, you can find solutions and overcome problems. The most appropriate way is through politics, with the intervention of different individuals, groups, and networks, for that we need diffusion of innovation (Dearing \& Cox, 2018).

The theory of diffusion of innovation (DOI), as proposed by Everet E. Roger, which was originally presented in his book in 1962, suggested that innovation diffusion originates from communication to explain how, over time, an idea or product gains momentum and spreads (or spreads) in a population, or a particular social system. The key to adoption is that the person must see the idea, behavior, or product as new or innovative (Rogers, 1971). E-government is one of the technological innovations in government that utilizes digitalization in the implementation of government activities.

E-government refers to the use of ICT by governments as applied to the full range of government functions (EOCD Report, 2003). It helps to improve the effectiveness of government services to the public, officials, business sectors, and other sectors (Carter \& Belanger, 2005; Huang, 2006; Warkentin et al., 2002). Continuous optimization of services, community, and government participation can form an integrated internal and external relationship through technology, the internet, and other new media. This interaction exists because the government carries out its duties in providing services to the community.

E-government, which is a product of the government, will not be able to be implemented 
without the role of the government itself. One of the reasons for the increasing development of e-government in developed countries is the high role of politics. For example, the Netherlands has a strong commitment to using the technology contained in its political system (United Nations, 2020). In politics, it is influenced by political policies and actions. Political factors that can explain policy factors are represented by political will. Political will is a complicated issue today (Cash, 2016). Political will is defined as good intentions shown by a power holder or political actor (Kpundeh, 1998). Political will is the desire of leaders in making programs for the development of services to the community (Angguna et al., 2015). However, a fairly standard definition of political will is that it refers to the extent to which support commitments among key decision-makers become policy solutions, in this study, the implementation of e-government.

Political will explanations are believed to be useful when other explanations for policy success or failure can be convincing. Because political will certainly be positively correlated with the expectations that the government wants to realize. However, it is important to note that political will usually be accompanied by "political action" (Brinkerhoff, 2000). This is because the Indonesian bureaucracy is Top-Down, namely the leader plays an important role in making decisions. The relationship with ICT is that technology digitalization affects elite decisions to change various possibilities in government (Fountain, 2011).

Bwalya (2009) finds that political will contributes to the delay in the adoption of digital government, because political elite, which is the head of government, has a higher position to encourage the success of e-government (Hapsara et al., 2017). Through political will, the desire of leaders or political elites at the individual and organizational levels functions to influence and provide policies to institutions and can control existing resources (Clemens \& Cook, 1999).

Infrastructure is a resource in technology. Information and communication technology infrastructure is one of the prerequisites for ev- ery activity in terms of technology, technicality, and other supporting tools. ICT and computers play an important role in providing stimulus and enhancement for e-government from one level to the next (Siau \& Long, 2009). ICT infrastructure can be considered a prerequisite for the development of e-government (Krishnan \& Teo, 2012). The incompleteness of ICT infrastructure and the low level of IT own are weaknesses in the digital governance process (AlBusaidy \& Weerakkody, 2008), so that information and communication technology infrastructure is recognized as a major challenge in digital governance (Elnaim, 2014).

The availability of ICT infrastructure must be supported by other aspects. The problem of procurement needs to be resolved quickly because it involves budget and financial conditions to make infrastructure available, a rather challenging prerequisite. Strong political will can break these barriers because the main driver comes from the head of government (Alshehri \& Drew, 2010). It is hoped that the problem in the procurement of ICT infrastructure can be resolved if there is a joint commitment from the executive and the legislative board in the form of political will. Support from the higher-level people is essential to obtain the necessary resources.

Human resources (HR) producing and running the system trigger the success of a system; in other words, HR is part of the success of e-government. Unskilled and untrained personnel in ICT has been the main obstacle to technology development (Eyob, 2004). HR also plays a significant role in the development of e-government (Anthopoulus et al., 2015; Das et al., 2016; Harijadi \& Satriya, 2000; Huang \& Bwoma, 2003; Ifinedo, 2011; Krishnan \& Teo, 2012; Reddick, 2004; Singh et al., 2004).

Previous studies confirmed that human resources were an important part in running a system, both administratively and technically (Das et al., 2016; Harijadi \& Satriya, 2000; Huang \& Bwoma, 2003; Ifinedo, 2011; Krishnan \& Teo, 2012; Singh et al., 2004; United-Nation, 2002). This means that success in applying e-government needs reliable human resources in ICT, 


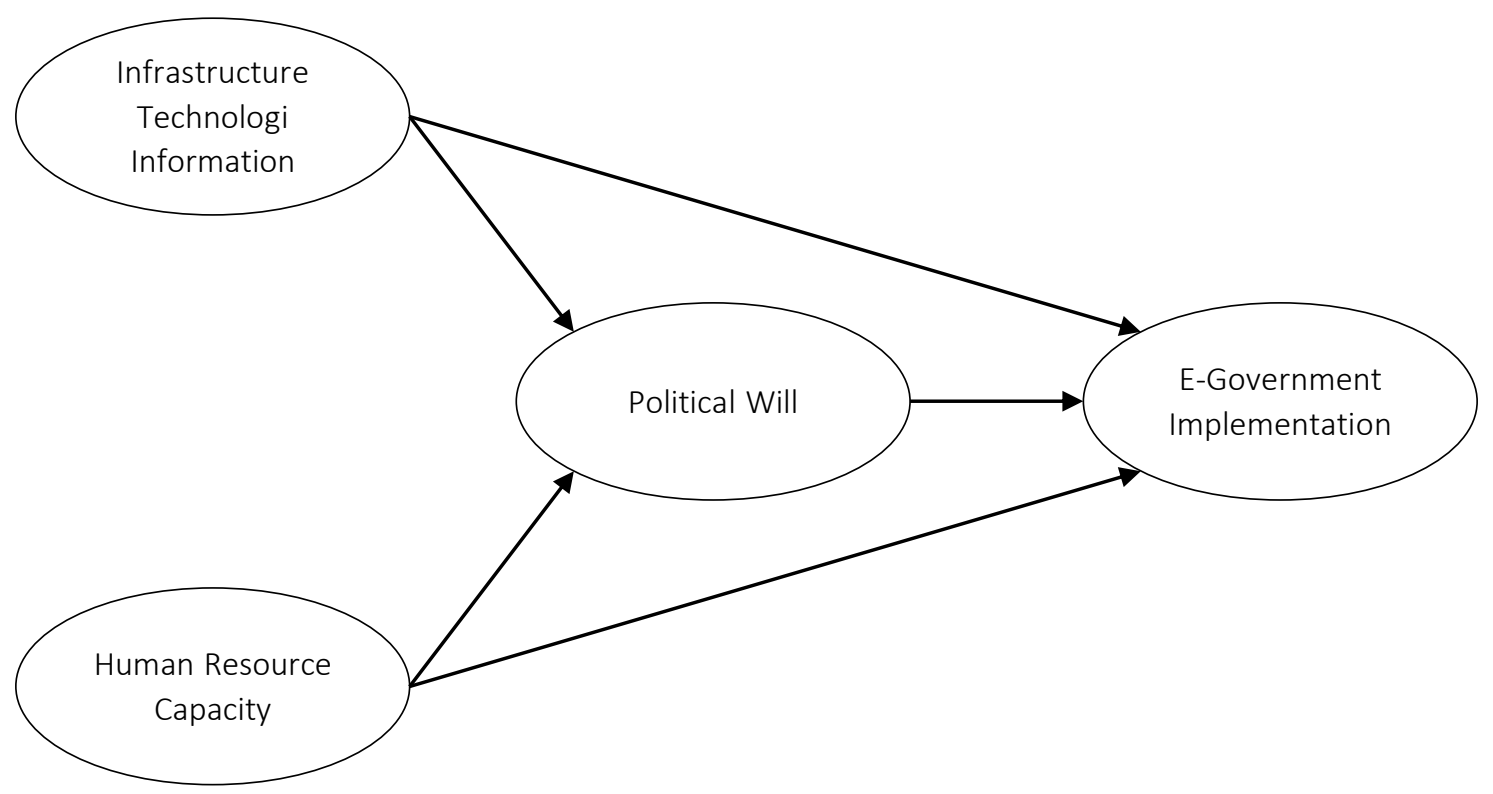

Figure 1. Research conceptual framework

both in creating and using ICT. This requires the government's attention to increase the potential of human resources. Figure 1 shows the composition of each factor that is a problem and will be discussed in this study, where political will can explain the role of direct relationships or as intermediaries from other factors, namely information technology infrastructure and human resource capacity for e-government implementation.

\section{AIMS AND HYPOTHESIS DEVELOPMENT}

The purpose of this study is to empirically prove that political will has a direct effect on the implementation of e-government and to examine the influence of ICT infrastructure and human resources on e-government that can be mediated through political will. Research hypotheses that can be built to answer the research objectives based on the literature review are presented:

H1: Political will has a direct effect on the implementation of e-government.

H2: Information and communication technology infrastructure has a positive and significant effect on e-government implementation.
H3: Human resources have a positive and significant effect on the implementation of e-government.

H4: Political will can mediate the relationship between IT infrastructure and human resources on the implementation of e-government.

\section{METHODS}

This study uses a quantitative approach with multivariate analysis (Sarstedt et al., 2017). The study started with a theory that is not fixed and aimed to test the predictive relationship between constructs. Data was collected through a survey method, namely by distributing questionnaires directly to respondents. Respondents are heads of Regional Apparatus Organizations (OPD) located in 19 district and city governments in West Sumatra Province, Indonesia. The questionnaire used a closed type, in the form of a statement using a 5-point Likert scale measurement, with alternatives from Strongly Disagree to Strongly Agree.

The data that has been collected is 263 samples through the non-probability quota sampling technique, this is selected based on a very wide area. Partial Least Square - Structural Equational Modeling (PLS-SEM) was used for 
statistical testing and finding research results. The validity test uses the Calculate Algorithm and answers the hypothesis using bootstrap testing on the SmartPLS software. The hypothesis will be answered if the significance is $<0.05$ and $\mathrm{T}$ count $>1.96$ then the decision is a supported hypothesis

\section{RESULT}

Determining the characteristics of respondents needs to be shown to illustrate that this study uses data on respondents' perceptions, which, of course, will affect the results of the study. In addition, these results will be the basis for interpreting data and analyzing test results. Table 1 showed the characteristics of respondents.

Table 1 describes the characteristics of respondents. Most respondents were male $(71.10 \%)$, and most respondents were above 51 years old (34\%). Most respondents held a Bachelor's Degree (47.53\%), while only a few held the Doctoral Degree (1.14\%) and graduated High School (1.14\%). Most respondents had become the heads of OPD for more than 10 years $(20.68 \%)$, they were the majority of respondents in this study.

PLS, using SmartPLS software, starts with an evaluation of the measurement model followed by an analysis of the structural model. This analysis was used to determine how the indicators of the manifest variable showed the latent variable to be measured. The first step was to test the validity of the reflective indicators. The test used a correla- tion between the indicator score and the construct score. The test results are shown in Figure 2.

Tests of construct validity and instrument reliability were carried out in the measurement model (Outer Model). The validity test was conducted to determine the ability of the research instrument to measure what should be measured. The reliability test was used to measure the consistency of instruments in measuring the concept; in other words, it was used to measure the consistency of respondents in answering items in questionnaires as research instruments.

The validity test was done by looking at convergent validity and discriminant validity in Table 2 . Convergent validity can be seen from the loading factor - the higher the loading factor value, the more important the role of loading is in interpreting the loading matrix. The rule of thumb used for convergent validity is outer loading $>0.70$, communality $>0.5$, and the value of Average Variance Extracted $(\mathrm{AVE})>0.5$. Figure 2 shows that the loading factor for all items is more than 0.7, except for item 1 (0.669). However, the indicator item was not deleted because the AVE and communality scores were $>0.5$.

Discriminant validity could be seen through the AVE root for each construct, in which it was greater than the correlation between constructs in the model. Meanwhile, the reliability test is used to measure the internal consistency of the measuring instrument. Reliability is measured by looking at Cronbach Alpha and composite reliability - the values should be $>0.7$. Table 3 illustrates that the value of Cronbach Alpha and composite reliability is $>0.7$.

Table 1. Characteristics of respondents

Source : Primary Data Analysis (2020).

\begin{tabular}{|c|c|c|c|}
\hline Characteristic & Groups & Number & Percentage \\
\hline \multirow{2}{*}{ Sex } & Male & 187 & $71.10 \%$ \\
\hline & Female & 76 & $28.90 \%$ \\
\hline \multirow{4}{*}{ Age } & $<40$ years old & 82 & $31 \%$ \\
\hline & $40-45$ years old & 42 & $16 \%$ \\
\hline & $46-50$ years old & 50 & $19 \%$ \\
\hline & $>51$ years old & 89 & $34 \%$ \\
\hline \multirow{4}{*}{ Education } & Senior High School & 3 & $1.14 \%$ \\
\hline & Bachelor & 132 & $50.19 \%$ \\
\hline & Master & 125 & $47.53 \%$ \\
\hline & Doctor & 3 & $1.14 \%$ \\
\hline \multirow{3}{*}{ Tenure } & $<5$ years & 34 & $12.93 \%$ \\
\hline & $1-10$ years & 33 & $13.80 \%$ \\
\hline & $>10$ years & 196 & $20.68 \%$ \\
\hline
\end{tabular}




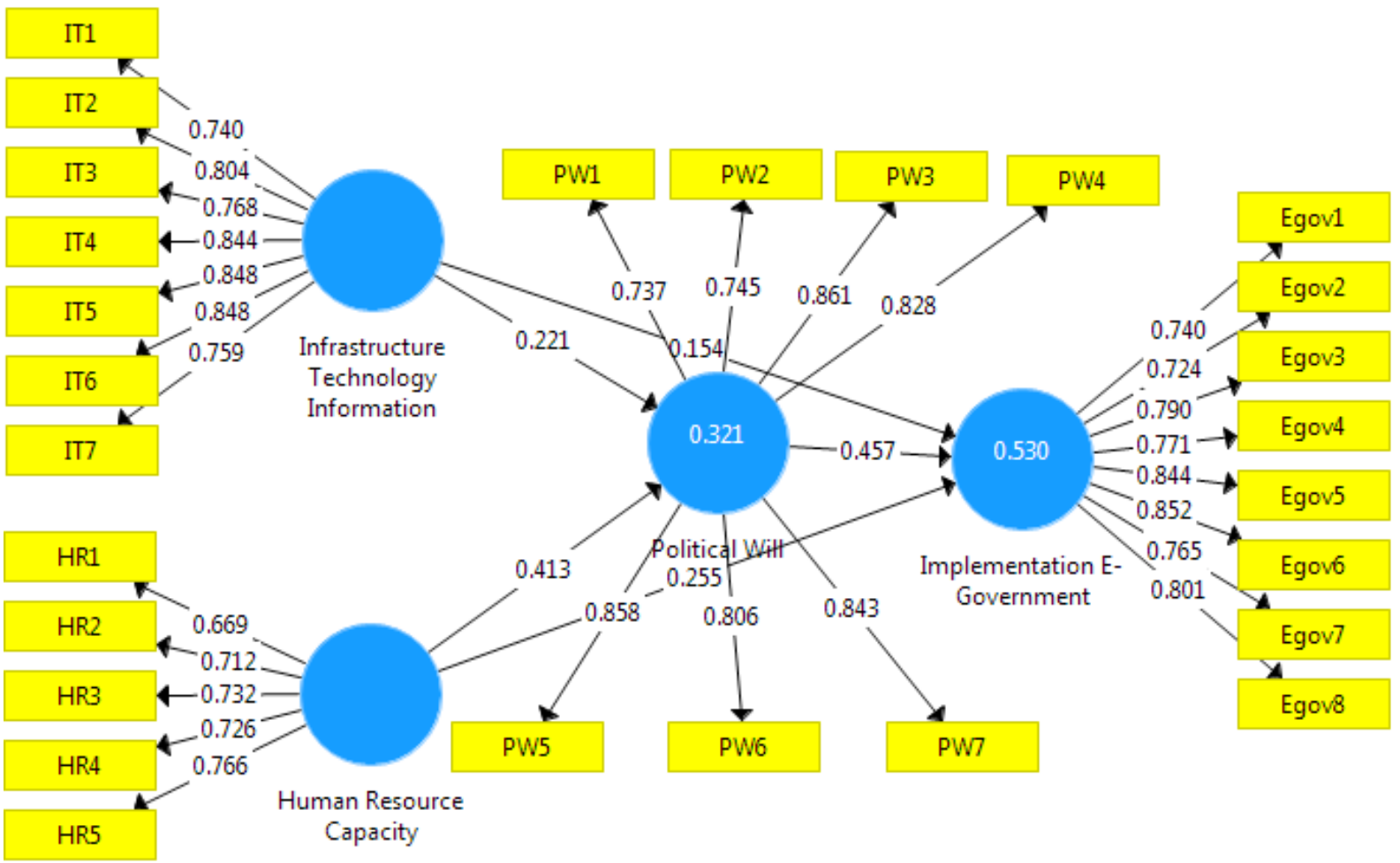

Figure 2. Convergent validity results

HR capacity and ICT infrastructure moderately explained $53 \%$ of the variance in the implementation of e-government, while the political will only explained $32.1 \%$ of the variance in the HR capacity and ICT infrastructure (Figure 2). Therefore, the model formed was categorized as a good model because it had a moderate relationship with the criterion value of $R^{2}$ greater than $25 \%$. A comparison of $T$-table value and $T$-statistic can be used as a measure of significance. If the T-statistic is higher than the T-table, it means that the hypothesis is accepted. For the 95\% confidence level (alpha 5\%), it is known that the $T$-table value is 1.96 (Sarstedt et al., 2017).
Answering the research hypothesis can be seen from direct and indirect testing, which can be summarized in Table 4. The direct path between political will and the implementation of e-government has a positive $(\beta=0.457)$ and significant $(t=$ 6.791) correlation; thus, the hypothesis is accepted, meaning that political will has a positive and significant effect on the implementation of e-government. Leaders who can carry out their electronicbased government activities show their political will. Political will represents the desire of leaders in making programs for good services to the community supported by the legislative board as rep-

Table 2. Validity test results

Source: Data analyzed using SmartPLS.

\begin{tabular}{|c|c|c|c|c|c|}
\hline \multirow{2}{*}{\multicolumn{2}{|c|}{ Criteria }} & \multicolumn{4}{|c|}{ Variable } \\
\hline & & Human Resources & Implementation of E-Government & ICT Infrastructure & Political Will \\
\hline \multirow{8}{*}{ Factor Loading } & Item 1 & 0.669 & 0.740 & 0.740 & 0.737 \\
\hline & Item 2 & 0.712 & 0.724 & 0.804 & 0.745 \\
\hline & Item 3 & 0.732 & 0.790 & 0.768 & 0.861 \\
\hline & Item 4 & 0.726 & 0.771 & 0.844 & 0.828 \\
\hline & Item 5 & 0.766 & 0.844 & 0.848 & 0.858 \\
\hline & Item 6 & - & 0.852 & 0.848 & 0.806 \\
\hline & Item 7 & - & 0.765 & 0.759 & 0.843 \\
\hline & Item 8 & - & 0.801 & - & - \\
\hline \multicolumn{2}{|c|}{ Discriminant Validity } & 0.722 & 0.787 & 0.803 & 0.812 \\
\hline
\end{tabular}


Table 3. Reliability test results

Source: Data analyzed using SmartPLS.

\begin{tabular}{l|c|c|c|c}
\hline \multicolumn{1}{c|}{ Variable } & $\begin{array}{c}\text { Cronbach's } \\
\text { Alpha }\end{array}$ & rho_A & $\begin{array}{c}\text { Composite } \\
\text { Reliability }\end{array}$ & $\begin{array}{c}\text { Average Variance } \\
\text { Extracted (AVE) }\end{array}$ \\
\hline Human Resource Capacity & 0.771 & 0.771 & 0.844 & 0.521 \\
\hline Implementation of E-Government & 0.912 & 0.914 & 0.929 & 0.620 \\
\hline ICT Information & 0.908 & 0.922 & 0.927 & 0.644 \\
\hline Political Will & 0.913 & 0.916 & 0.931 & 0.660 \\
\hline
\end{tabular}

resentatives of the community whose main duty is to supervise the activities of the leaders.

The direct path between ICT infrastructure and the implementation of e-government has a positive $(\beta=0.154)$ and significant $(t=2.640)$ correlation; thus, the hypothesis is accepted. This means the availability of ICT infrastructure significantly affected the implementation of e-government in regencies/cities in West Sumatera. Human resource capacity directly affects the implementation of e-government and shows a positive $(\beta=$ $0.255)$ and significant $(t=4.331)$ correlation. The findings of this study supported previous studies that human resource capacity is the driving force for organizations in creating innovation and running new technology (Wairiuko et al., 2018).

\section{DISCUSSION}

The results of this study add to the reference that the main factors for implementing e-government, namely infrastructure and the availability of human resources, have an effect on supporting the implementation of e-government to a better level. Likewise, the implementation of digital government requires adequate information technology infrastructure to facilitate e-government services (Bwalya, 2009). This means that weak infrastructure can create infrastructure barriers and obstacles that can affect the implementation of e-government services (Zeebaree et al., 2020).

However, the infrastructure owned is not following the needs because some infrastructure is still in the stage of being added and the budget problem is not sufficient. The limitations of human resources, both in terms of quality and quantity still exist, the placement of employees that are not following their competencies oc- curs a lot, this is an important influence in improving e-government, especially from implementation. The results of this study support the literature concluding that the quality of human resources can influence the success of innovation (Ariana et al., 2020).

Political will has a significant effect on the implementation of e-government because a government project will be carried out through the support and commitment of the regional head. Political will is the main thing that must be in the planning and development framework of e-government. Likewise, with the obstacles faced in the journey of e-government, the problem of resources is a challenge that is often faced in e-government, not only related to infrastructure and human resources but can be related to pressure factors and limitations in funding.

After all, the leader is one of the main drivers of every project, initiative, and innovation that come from the leadership, that high-level support is very important to obtain and manage the necessary resources (Alshehri \& Drew, 2010). This means that infrastructure and human resource problems can be overcome if there is a strong will to resolve them through a joint commitment from the executive and legislature in the form of political will.

However, the support element is the most important element in the development of e-government. It needs political will from public officials so that the concept of e-government can be applied. The same thing was also conveyed in the reference. Political elites running political functions should be able to mobilize existing resources to overcome challenges in realizing successful e-government; one of the ways that may be done is to ensure that regulations are implemented well (Almarabeh \& Abuali, 2010). 
Table 4. Bootstraping test results

Source: Data analyzed using SmartPLS.

\begin{tabular}{|c|c|c|c|c|c|}
\hline Variable & $\begin{array}{c}\text { Original } \\
\text { Sample } \\
\text { (O) }\end{array}$ & $\begin{array}{c}\text { Standard } \\
\text { Deviation } \\
\text { (STDEV) }\end{array}$ & $\begin{array}{l}\text { T Statistics } \\
\text { (|O/STDEV|) }\end{array}$ & $\begin{array}{c}P \\
\text { Values }\end{array}$ & $\begin{array}{l}\text { Results } \\
\text { Hypothesis }\end{array}$ \\
\hline \multicolumn{6}{|c|}{ Direct Path } \\
\hline Political Will $\rightarrow$ Implementation of E-Government & 0.457 & 0.067 & 6.791 & 0.000 & Supported \\
\hline IT Infrastructure $\rightarrow$ Implementation of E-Government & 0.154 & 0.058 & 2.640 & 0.009 & Supported \\
\hline $\begin{array}{l}\text { Human Resource Capacity } \rightarrow \text { Implementation of } \\
\text { E-Government }\end{array}$ & 0.255 & 0.059 & 4.331 & 0.000 & Supported \\
\hline \multicolumn{6}{|c|}{ Political Will as a Mediating Variable } \\
\hline $\begin{array}{l}\text { IT Infrastructure } \rightarrow \text { Political Will } \rightarrow \text { Implementation of } \\
\text { E-Government }\end{array}$ & 0.101 & 0.033 & 3.078 & 0.002 & Supported \\
\hline $\begin{array}{l}\text { Human Resource Capacity } \rightarrow \text { Political Will } \rightarrow \\
\text { Implementation of E-Government }\end{array}$ & 0.188 & 0.041 & 4.619 & 0.000 & Supported \\
\hline
\end{tabular}

The existence of regulations can encourage and accelerate regions to implement e-government. This is evident from several regions that have issued regional regulations regarding the implementation of e-government as a step in implementing the bureaucracy in supporting the implementation of public services. Although it has not yet moved to a higher stage, without various development initiatives, e-government development will be difficult.

\section{CONCLUSIONS}

This study was developed to know the role of political will as a political factor in influencing e-government. The test results prove that political will has a strong influence on the main factors of e-government implementation, namely ICT infrastructure and human resources. Significant and positive political will has a direct effect on the implementation of e-government. The stronger the leadership commitment by providing real support, the faster the progress of using an electronic government system. For example, by issuing regional regulations that carry out activities using technology. The results of the study also found that political will was able to play a role in mediating the relationship between ICT infrastructure and human resources on the implementation of e-government. These results indicate that the strong will of the political elite can overcome various obstacles that occur in the implementation of a technological innovation in government.

The results also support previous literature that ICT infrastructure and human resources have a positive effect on e-government implementation. Thus, this study indicates that technological factors and human quality are the main factors that can contribute to a mature e-government improvement and become government obstacles if they are not considered optimally.

\section{AUTHOR CONTRIBUTIONS}

Conceptualization: Siska Yulia Defitri.

Data curation: Siska Yulia Defitri.

Formal analysis: Siska Yulia Defitri.

Funding acquisition: Siska Yulia Defitri.

Investigation: Siska Yulia Defitri.

Methodology: Siska Yulia Defitri.

Project administration: Siska Yulia Defitri.

Resources: Siska Yulia Defitri.

Software: Siska Yulia Defitri. 
Supervision: Siska Yulia Defitri.

Validation: Siska Yulia Defitri.

Visualization: Siska Yulia Defitri.

Writing - original draft: Siska Yulia Defitri.

Writing - review \& editing: Siska Yulia Defitri.

\section{REFERENCES}

1. Aboluwodi, A. (2015). Political Will and Strategic Planning in the Implementation of Universal Basic Education in Nigeria: The Obafemi Awolowo Example. Journal of Education and Research, 5(1), 41-55. https://doi.org/10.3126/jer. v5i1.13057

2. Adam, I. O. (2020). Examining E-Government Development Effects on Corruption in Africa: The Mediating Effects of ICT Development and Institutional Quality. Technology in Society, 61(February), 1-10. https://doi. org/10.1016/j.techsoc.2020.101245

3. Al-Busaidy, M., \& Weerakkody, V. (2008). Factors Influencing E-Government Implementation Progress in Oman: a Discussion. In European and Mediterranean Conference on Information Systems (pp. 1-9).

4. Almarabeh, T., \& Abuali, A. (2010). A General Framework for E-Government : Definition Maturity Challenges, Opportunities, and Success. European Journal of Scientifich Research, 39(1), 29-42.

5. Alshehri, M., \& Drew, S. (2010). Implementation of e-Government: Advantages and Challenges. In IASK International Confrerence EActivity and Leading Technologies \& Inter TIC (pp. 79-86).

6. Angguna, Y. P., Gani, A. Y. A., \& Sarwono. (2015). Upaya Pengembangan E-Government dalam Pelayanan Publik pada Dinas Koperasi dan UKM Kota Malang. Jurnal Administrasi Publik (JAP), 3(1), 80-88.

7. Anthopoulus, L., Reddick, C. G., Giannakidou, I., \& Mavridis, N. (2015). Why e-government Projects Fail? an Analysis of the Healthcare.gov Website. Government Information Quarterly. https://doi.org/10.1016/j. giq.2015.07.003
8. Apleni, A., \& Smuts, H. (2020). An e-Government Implementation Framework: A Developing Country Case Study. International Federation for Information Processing, 15-27. https://doi. org/10.1007/978-3-030-45002-1_2

9. Ariana, S., Azim, C., \& Antoni, D. (2020). Clustering of ICT Human Resources Capacity in the Implementation of E-government in Expansion Area: a Case Study From Pali Regency. Cogent Business and Management, 7(1). https://doi.org/ 10.1080/23311975.2020.1754103

10. Brinkerhoff, D. W. (2000). Assessing Political Will for AntiCorruption Efforts: an Analytic Framework. Public Administration and Development, 20, 239-252.

11. Bwalya, K. J. (2009). Factors Affecting Adoption of e-Government in Zambia. The Electronic Journal on Information System in Developing Countries (EJISDC), 38(4), 1-13. https://doi. org/10.1002/j.1681-4835.2009. tb00267.x

12. Carter, L., \& Belanger, F. (2005). The Utilization of E-government Services: Citizen Trust, Innovation and Acceptance Factors. Information Systems Journal, 15, 5-25. https://doi.org/10.1111/j.13652575.2005.00183.x

13. Cash, C. (2016). Good Governance and Strong Political Will : Are They Enough for Transformation ? Land Use Policy, 50, 301-311. https://doi.org/10.1016/j.landusepol.2015.10.009

14. Clemens, E. S., \& Cook, J. M. (1999). Politics and Institutionalism: Explaining Durability and Change. Annual Review of Sociology, 25, 441-466. https://doi. org/10.1146/annurev.soc.25.1.441
15. Dada, D. (2006). The Failure of E-Government in Developing Countries: A Literature Review. The Electronic Journal of Information Systems in Developing Countries, 26(1), 1-10. https://doi. org/10.1002/j.1681-4835.2006. tb00176.x

16. Dahwan, A. A., \& Raju, V. (2021). The Infleuence of Online Services and Telecommunication Infrastructure on the Implementation of E-government in Military Institutions in Yemen. Annals of the Romanian Society for Cell Biology, 25(4), 1044-1056. Retrieved from http://annalsofrscb.ro

17. Danyliuk, M., Dmytryshyn, M., \& Goran, T. (2021). Informatization in Ukraine: Realities, Problems, Prospects. European Journal of Sustainable Development, 10(4), 190. https://doi.org/10.14207/ ejsd.2021.v10n4p190

18. Das, A., Singh, H., \& Joseph, D. (2016). Information \& Management A longitudinal study of e-government maturity. Information \& Management. https://doi. org/10.1016/j.im.2016.09.006

19. Dearing, J. W., \& Cox, J. G. (2018). Diffusion of innovations theory, principles, and practice. Health Affairs, 37(2), 183-190. https://doi. org/10.1377/hlthaff.2017.1104

20. Defitri, S. Y., Bahari, A., Handra, H., \& Febrianto, R. (2020). Determinant Factors of E-Government Implementation and Public Accountability: TOE Framework Approach. Public Policy and Administration, 19(4), 37-51. https:// doi.org/10.13165/VPA-20-19-4-03

21. Elnaim, B. M. E. (2014). An Overview of E-Government Strategy In Sudan. European Journal of Computer Science and Information Technology, 2(2), 1-9. 
22. EOCD Report. (2003). The Case for E-Government : Excerpts from the OECD Report "The E-Government Imperative." OECD Jurnal on Budgeting, 3(1), 61-96.

23. Eyob, E. (2004). E-government : Breaking the Frontiers of Inefficiencies in the Public Sector. Electronic Government, 1(1), 107-114. Retrieved from https:// www.inderscienceonline.com/doi/ abs/10.1504/EG.2004.004140

24. Fountain, J. (2011). Bringing Institutions Back In to Strategic Management: The Politics of Digitally Mediated Institutional Change. National Center for Digital Government Working Papers, 11(001), 1-48.

25. Hammergren, L. (1998). Political Will, Constituency Building, and Public Support in Rule of Law Programs.

26. Hapsara, M., Imran, A., \& Turner, T. (2017). Beyond Organizational Motives of e-Government Adoption: The Case of e-Voting Initiative in Indonesian Villages. Procedia Computer Science, 124, 362-369. https://doi.org/10.1016/j. procs.2017.12.166

27. Harijadi, D. A., \& Satriya, E. (2000). Indonesia’s Road Map to E-Government: Opportunities and Challenges. In APEC HighLevel Symposium on E-Government, Seoul, Korea (pp. 1-8).

28. Huang, Z. (2006). E-Government Practices At Local Levels: An Analysis of U.S. Counties' Websites. Issues in Information Systems, VII(2), 165-170.

29. Huang, Z., \& Bwoma, P. O. (2003). An Overview of Critical Issues of E-government. Issues of Information Systems, 4(1), 164-170. Retrieved from http://www.iacis. org/iis/2003_iis/PDFfiles/HuangBwoma.pdf

30. Ifinedo, P. (2011). Factors Influencing Maturity in Transition Economies and Developing Countries: A Longitudinal Perspective. Advance in Information Systems, 42(4), 98-116.

31. Ishaq, S. (2018). Political Will Drives Community Participation in Centrally Sponsored Watershed Development Programmes. International Journal of English
Languange, Literature in Humanities, 6(7), 679-691.

32. Kpundeh, S. J. (1998). Political Will in Fighting Corruption. United Nations Development Programme.

33. Krishnan, S., \& Teo, T. S. (2012). Moderating Effects of Governance on Information Infrastructure and E-Government Development. Journal of The American Society for Information Science and Technology. https://doi.org/10.1002/ asi. 22660

34. Kumajas, Y. N. (2021). The Effects of Human Resources Quality, Infrastructure, Leadership, and Communication on E-Government Implementation: A Case of Indonesia Local Government. Budapest International Research and Critics Institute (BIRCIJournal): Humanities and Social Sciences, 4(1), 597-612. https://doi. org/10.33258/birci.v4i1.1643

35. Manenji, T., \& Marufu, B. (2016). The Impact of Adopting E-government as a Mechanism to Enhance Accountability as well as Transparent Conduct Within Public Institutions. Scholedge International Journal of Business Policy \& Governance, 03(07), 84-101. https://doi.org/10.19085/journal. sijbpg030701

36. Michael, P., Dimitriou, S., Glyptis, L., \& Zarifis, A. (2018). E-Government Implementation Challenges in Developing Countries: The Project Manager's Perspective. International Journal of Public Administration and Management Research (IJPAMR), 4(3), 1-17.

37. Muhaya, F. Bin, Bakry, S. H., \& Alalmaee, S. M. (2015). E-Government Success Factors: Views of Saudi Professionals. Journal of Entrepreneurship \& Organization Management, 4(1), 1-6. https://doi. org/10.4172/2169-026X.1000128

38. Nkohkwo, Q. N., \& Islam, M. S. (2013). Challenges to the Successful Implementation of e-Government Initiatives in Sub-Saharan Africa: A Literature Review Research. Electronic Journal of EGovernment, 11(2), 253-267.

39. Odat, A. M. (2012). E-Government in Developing Countries: Framework of Challenges and Op- portunities. Journal of Theoretical and Applied Information Technology, 46(2), 1013-1021.

40. Pfano, M., \& Beharry, A. (2016). The Effect of Modern Office Technology on Management Performance: Durban Westville. Problems and Perspectives in Management, 14(2), 376-384. https:// doi.org/10.21511/ppm.14(22).2016.13

41. Ramli, R. M. (2017). E-government Implementation Challenges in Malaysia and South Korea: A Comparative Study. Electronic Journal of Information Systems in Developing Countries, 80(1). https://doi. org/10.1002/j.1681-4835.2017. tb00591.x

42. Rasyid, F. A., \& Dulkiah, M. (2020). Political Will Implementation of The Government in Hope Family Program Policy. Journal of Governance, 5(1). https://doi. org/10.31506/jog.v5i1.7597

43. Reddick, C. G. (2004). Empirical Models of E-Government Growth in Local Governments. E-Service Journal, 59-84.

44. Rogers, E. M. (1971). Diffusion of innovations. An Integrated Approach to Communication Theory and Research ( $3^{\text {rd }}$ ed.). United States of America: Library of Congress Cataloging. https://doi. org/10.4324/9780203710753-35

45. Sarstedt, M., Ringle, C. M., \& Hair, J. F. (2017). Partial Least Squares Structural Equation Modeling. Springer International Publishing. https://doi.org/10.1108/ebr-102013-0128

46. Siau, K., \& Long, Y. (2009). Factors Impacting E-Government Development. Journal of Computer Information Systems, September, 98-107.

47. Singh, H., Das, A., \& Joseph, D. (2004). Country-level determinants of e-Government Maturity.

48. Stier, S. (2015). Political Determinants of E-government Performance Revisited: Comparing Democracies and Autocracies. Government Information Quarterly, 32(3), 270-278. https://doi org/10.1016/j.giq.2015.05.004 
49. United-Nation. (2002). Benchmarking E-government : A Global Perspective Assessing the Progress of the UN Member States. U.N. Publications.

50. United Nations. (2020). E-Government Survey 2020 (Digital Government in the Decade of Action for Sustainable Development). New York. Retrieved from https://publicadministration.un.org/en/

51. Wairiuko, J. W., Nyonje, R., \& Omulo, E. O. (2018). Human Resource Capacity and Adoption of E-Government for Improved Service Delivery in Kajiado County,
Kenya. International Journal of Business and Social Science, 9(10), 94-110. https://doi.org/10.30845/ ijbss.v9n10p10

52. Warkentin, M., Gefen, D., Pavlou, P. A., \& Rose, G. M. (2002). Encouraging Citizen Adoption of e-Government by Building Trust. Electronic Markets, 12(3), 157-162.

53. Weerakkody, V., Dwivedi, Y. K., \& Kurunananda, A. (2009). Implementing E-Government in Sri Lanka: Lessons from the UK. Information Technology for Development, 15(3), 171-192. https://doi. org/10.1002/itdj
54. Weerakkody, V., El-Haddadeh, R., \& Al-Shafi, S. H. (2011). Exploring the complexities of E-government Implementation and Diffusion in a Developing Country: Some Lessons from the State of Qatar. Journal of Enterprise Information Management, 24(2), 172-196. https://doi. org/10.1108/17410391111106293

55. Zeebaree, M., Sattar, S., Ismael, G. Y., Qader, A. N., \& Aqel, M. (2020). Impact of Infrastructure Barriers on Electronic Government Implementation. Estudios de Economia Aplicada, 38(4), 1-15. https://doi. org/10.25115/EEA.V38I4.3971 